\title{
DESKRIPSI KEMAMPUAN PENALARAN MATEMATIS SISWA SMP PADA MATERI ARITMATIKA SOSIAL
}

\author{
${ }^{1)}$ Veronika Oktaviana, ${ }^{2)}$ Indrie Noor Aini \\ ${ }^{1,2)}$ Universitas Singaperbangsa Karawang, Jln. H.S Ronggo Waluyo, Karawang, 41361 \\ 1710631050174@student.unsika.ac.id
}

\begin{abstract}
Received:

13-03-2021

The purpose of this study was to determine student's mathematical reasoning ability in social arithmetic material. This type of study is qualitative with descriptive method. The subjects used in this study were 37 students of $8^{\text {th }}$ grade junior hight school 13 Bekasi City then selected the subjects by purposive

Accepted :

28-04-2021 sampling namely one student who had high, medium, and low of mathematical ability. The research instrument used in this study namely one test in the form of an open-ended description on the indicator of mathematical reasoning ability which is to checking the validity of an argument in social arithmetic material.

Published :

05-05-2021 Data collection techniques in this research carried out were data that had been obtained analyzed with descriptive statistics and interviews were analyzed using the Miles and Huberman model. Based on the results of the analysis of the answer of each student's, namely students with high and medium of mathematical ability have been able to solve problem in social arithmetic material and meet one indicator of mathematical reasoning ability namely checking the validity of an argument, then student with low of mathematical ability have not been able to solve problem in the social arithmetic material and does not meet one indicator of mathematical reasoning ability namely checking the validity of an argument.
\end{abstract}

Keywords: Mathematical Reasoning, Social Arithmetic, Mathematical Ability

\begin{abstract}
Abstrak
Tujuan dari penelitian yang terlaksana ini yakni mengetahui kemampuan penalaran matematis siswa pada pokok bahasan materi aritmatika sosial. Jenis dari penelitian yang terlaksana ini yaitu kualitatif dengan metode deskriptif. Subjek pada penelitian yang terlaksana ini sebanyak 37 siswa kelas VIII SMP Negeri 13 Kota Bekasi kemudian dilakukan pemilihan subjek secara purposive sampling yaitu dilakukan pemilihan masing-masing satu siswa yang mempunyai kemampuan matematis tinggi, sedang, dan rendah. Instrumen penelitian yang digunakan dari penelitian ini yaitu satu soal tes berupa uraian open-ended pada indikator kemampuan penalaran matematis yakni memeriksa kesahihan suatu argumen dalam pokok bahasan materi aritmatika sosial. Teknik pengumpulan data pada penelitian yang terlaksana ini adalah data yang telah diperoleh dilakukan analisis dengan statistik deskriptif serta wawancara dilakukan analisis dengan model Miles dan Huberman. Berdasarkan hasil analisis terhadap jawaban masing-masing siswa yaitu siswa berkategori kemampuan matematis tinggi dan sedang sudah mampu menyelesaikan permasalahan pada materi aritmatika sosial dan memenuhi satu indikator kemampuan penalaran matematis yakni memeriksa kesahihan suatu argumen, kemudian siswa berkategori kemampuan matematis rendah belum mampu menyelesaikan permasalahan pada materi aritmatika sosial dan tidak memenuhi satu indikator kemampuan penalaran matematis yaitu memeriksa kesahihan suatu argumen.
\end{abstract}

Kata Kunci: Penalaran Matematis, Aritmatika Sosial, Kemampuan Matematis

\section{Pendahuluan}

Pendidikan adalah sebuah upaya dengan cara pemberian pengetahuan dalam pembelajaran sehingga dapat mencerdaskan kehidupan bagi bangsa. Rancangan untuk mencerdaskan kehidupan bagi bangsa maka dapat meningkatkan pada kualitas dalam pendidikan. Pendidikan berisikan peranan penting pada rutinitas sehari-hari sehingga 
harus diperkenalkan serta diterapkan sejak dini. Pendidikan yang dipunyai pada setiap individu dapat dikembangkan secara otodidak maupun bantuan dari orang lain.

Berdasarkan penjelasan sebelumnya bahwa pendidikan individu dapat dikembangkan dengan cara berbantuan dari orang lain yang dimaksudkan adalah salah satunya sebuah lembaga pendidikan yang mempunyai tujuan untuk menghasilkan pendidikan pada masa kini dan maju serta bertambah pesat mempunyai mutu terbaik serta berkualitas (Fitriatien, 2019). Pada masa kini terdapat perkembangan yang sangat pesat dalam pendidikan yaitu dari salah satu mata pelajaran matematika, dimana memberikan partisipasi pada perkembangan teknologi, informasi, serta komunikasi (Haeruman et al., 2017).

Matematika adalah suatu mata pelajaran dengan mempunyai bagian yang terpenting untuk setiap jenjang pada pendidikan serta menjadi dasar pengetahuan untuk mata pelajaran lainnya khususnya berhubungan dengan sains. Pada pembelajaran matematika dimana siswa diharuskan mempunyai kemampuan-kemampuan yang terdapat pada matematika adalah 1. Memahami konsep, 2. Menggunakan penalaran, 3. Pemecahan masalah, 4. Mengkomunikasikan gagasan, 5. Memiliki sikap menghargai kegunaan matematika (Permendikbud, 2016).

Pembelajaran pada matematika mempuyai standar isi yaitu siswa dapat mengaplikasikan kemampuan matematis yaitu salah satunya penalaran dengan menggunakan berbagai pola, sifat, menggunakan manipulasi matematika serta membuat generalisasi, pembentukan terhadap bukti, serta menjelaskan suatu gagasan dari pertanyaan (Departemen Pendidikan Nasional dalam Burais et al., 2016). Berdasarkan penjelasan sebelumnya bahwa siswa harus dapat menguasai dan mengaplikasikan kemampuan matematis pada saat belajar dengan pembahasan matematika. Maka ketika siswa menguasai adanya kemampuan penalaran matematis baik sehingga memberikan kemudahan bagi siswa untuk memahami dan melaksanakan kegiatan belajar matematika dengan optimal.

Penalaran matematis adalah sebuah aktivitas dalam berfikir untuk menetapkan suatu argumen yang berkaitan dengan matematika untuk penilaian benar atau salah kemudian berikutnya dapat memberikan argumen berkaitan dengan matematika yang baru (Sri Sumartini, 2015). Sedangkan Kemampuan penalaran matematis adalah kemampuan dalam berfikir untuk menggabungan sebuah permasalahan terhadap suatu pada ide maupun gagasan maka dapat menyelesaikan sebuah permasalahan dan 
memberikan kesimpulan yang berkaitan dengan matematika (Salmina \& Nisa, 2018). Kesimpulan tercipta dari adanya proses penalaran berdasarkan pengetahuan yang dimiliki siswa sebelumnya (Conner et al., 2014). Pada penjelasan sebelumnya dapat disimpulkan kemampuan penalaran matematis adalah sebuah keterampilan dengan cara berfikir untuk penarikan sebuah penyimpulan terhadap hasil dari penyelesaian permasalahan yang mempunyai hubungan dengan matematika.

Kemampuan penalaran matematis merupakan kemampuan matematika dengan memiliki peranan terpenting bagi jalanya proses belajar untuk materi matematika. Namun berdasarkan hasil wawancara bersama guru matematika bahwa rendahnya kemampuan penalaran matematis yang dikuasai oleh siswa dikarenakan siswa belum mampu memenuhi salah satunya pada indikator kemampuan penalaran matematis yakni memeriksa kesahihan suatu argumen. Penjelasan sebelumnya sejalan dengan penelitian (Aprilianti \& Zhanty, 2019) bahwa kemampuan penalaran matematika yang dimiliki siswa masih tergolong rendah dibuktikan pada hasil dalam penelitian bahwa siswa kurang memahami empat indikator kemampuan penalaran matematis yakni salah satunya indikator memeriksa kesahihan suatu argumen sebesar 1,5 dengan berkategori rendah.

Kemampuan penalaran memberi manfaat bagi siswa dalam membantu menyelesaikan permasalahan pada materi matematika sehingga membangun serta mengembangkan kemampuan yang terdapat didalam diri siswa (Ongcoy, 2016). Siswa yang sudah dapat menggunakan penalaran dalam mengatasi permasalahan dalam kehidupan sehari-hari maka siswa sudah memiliki keterampilan dalam mencari sebuah bukti, fakta, serta ketepatan dengan cara proses bernalar yang benar (Moneva et al., 2020). Pada pernyataan sebelumnya yakni kemampuan penalaran matematis dengan materi pembelajaran matematika memiliki keterkaitan dalam penerapan kehidupan sehari-hari yaitu salah satunya materi aritmatika sosial. Contoh materi aritmatika sosial antara lain penjualan dan pembelian, bunga tabungan, dan lain sebagainya.

Berdasarkan hasil penelitian (Aziz, H. E., \& Hidayati, 2019) yaitu kemampuan penalaran matematis yang dikuasai oleh siswa untuk penyelesaian materi aritmatika sosial dapat dikategorikan rendah dikarenakan siswa kurang memahami penjelasan dari pertanyaan pada soal maka siswa belum memenuhi satu indikator dari kemampuan penalaran matematis. Pada pernyataan sebelumnya yakni pentingnya kemampuan penalaran matematis didalam pokok bahasan materi aritmatika sosial serta terdapat 
perbedaan karakter pada siswa ketika menyelesaikan soal kemampuan penalaran matematis dengan bahasan aritmatika sosial. Maka peneliti mempunyai tujuan melakukan deskripsi kemampuan penalaran matematis yang dipunyai oleh siswa dengan pembahasan aritmatika sosial berdasarkan tingkatan hasil dalam belajar pada matematika tinggi, sedang, dan rendah.

\section{Metode Penelitian}

Jenis penelitian yang terlaksana ini yaitu penelitian kualitatif dengan metode deskriptif. Subjek penelitian ini adalah siswa kelas VIII SMP Negeri 13 Kota Bekasi tahun pelajaran 2020/2021 dengan berjumlah 37 siswa kemudian dipilih 3 siswa sebagai subjek penelitian. 3 Subjek yang terpilih secara purposive sampling dengan pertimbangan berdasarkan tujuan tertentu (Sugiyono, 2019). Pertimbangan pemilihan 3 subjek berdasarkan penilaian akhir semester 1 kelas VIII tahun pelajaran 2020/2021 serta rekomendasi dari guru matematika untuk dilakukan wawancara secara mendalam dari masing-masing satu subjek kemampuan matematis tinggi, dan sedang, serta rendah. Instrumen penelitian yang terlaksana ini yaitu satu soal tes yang berupa uraian openended pada indikator kemampuan penalaran matematis yakni memeriksa kesahihan suatu argumen dalam materi aritmatika sosial yang diadopsi serta telah dilakukan uji validitas terlebih dahulu oleh penelitian dari (Adilla Nur, Desianty \& Nurhabibah, 2020). Pengkategorian nilai siswa yang telah dijelaskan sebelumnya dengan beradasarkan perhitungan (Riduwan dalam Mulyati \& Farkhah, 2020).

Tabel 1. Rentang Pengkategorian Kemampuan

\begin{tabular}{ll}
\hline Kategori & Rumus Rentang \\
\hline Tinggi & $X \geq(\mu+\sigma)$ \\
Sedang & $(\mu-\sigma) \leq X<(\mu+\sigma)$ \\
Rendah & $X<\mu-\sigma$ \\
\hline
\end{tabular}

Keterangan :

$\mathrm{X}=$ Skor Nilai, $\mu=$ Rata - Rata, $\sigma=$ Standar Deviasi

Penilaian teknik pada pengumpulan data dari penelitian yang terlaksana ini yaitu tes, dan wawancara, serta dokumentasi dalam mengetahui kemampuan penalaran matematis yang dikuasai siswa. Pengecekan sebuah keabsahan data dari penelitian yang terlaksana ini menerapkan triangulasi sumber adalah memakai tes, wawancara, serta dokumentasi sebagai bahan perbandingan. Analisis data yang terlaksana ini antara lain 1. Reduksi Data, 2. Penyajian Data, 3. Penarikan Kesimpulan (Miles dan Huberman dalam Sugiyono, 2018). 


\section{Hasil dan Pembahasan}

Berdasarkan perolehan hasil pada penelitian diperoleh data jumlah serta presentase kemampuan matematis subjek :

Tabel 2. Kategori Kemampuan Matematis Subjek

\begin{tabular}{llllll}
\hline Rentang Nilai & Kategori & Frekuensi & Presentase & \multicolumn{2}{c}{ Data Subjek } \\
\cline { 5 - 6 } & & & & Nilai PAS & Inisial \\
\hline $\mathrm{X} \geq 62,53$ & Tinggi & 3 & $8,1 \%$ & 85 & $\mathrm{~S} 1$ \\
$33,88 \leq \mathrm{X}<62,53$ & Sedang & 29 & $78,4 \%$ & 60 & $\mathrm{~S} 2$ \\
$\mathrm{X}<33,88$ & Rendah & 5 & $13,5 \%$ & 30 & $\mathrm{~S} 3$ \\
\hline
\end{tabular}

Berdasarkan pada Tabel.1 bahwa diperoleh hasil dari kategori kemampuan matematis siswa antara lain yaitu kategori kemampuan matematis siswa tinggi dengan inisial S1 memperoleh presentase sebesar 8,1\%, sedangkan kategori kemampuan matematis siswa sedang dengan inisial S2 memperoleh presentase sebesar 78,4\%, serta kategori kemampuan matematis siswa rendah dengan inisial S3 memperoleh presentase sebesar 13,5\%. Berdasarkan hasil kategori kemampuan matematis siswa yang sebelumnya telah dijelaskan bahwa akan terpilih satu siswa dari setiap tingkatan kategori yaitu tinggi dengan inisial S1, sedang dengan inisial S2, dan rendah dengan inisial S3 untuk dijadikan sebagai subjek penelitian serta melakukan analisis terhadap hasil jawaban masing-masing siswa pada tes kemampuan penalaran matematis berdasarkan indikator yang ingin dicapai yaitu memeriksa kesahihan suatu argumen kemudian melaksanakan wawancara dengan semakin dalam yang bertujuan memperoleh data dan penjelasan lebih rinci serta mendalam. Berikut hasil analisis jawaban dari ketiga subjek:

\section{a. Kemampuan Matematis Tinggi (S1)}

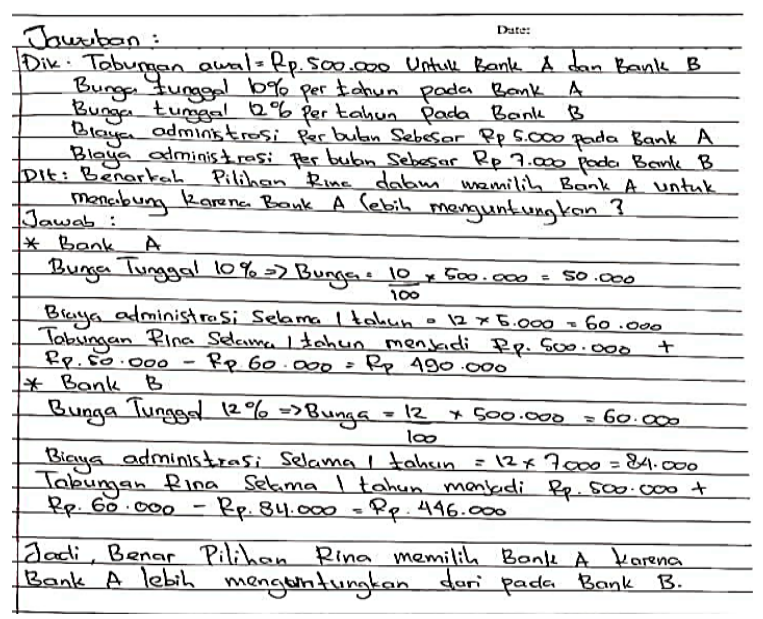

Gambar 1. Jawaban Siswa Berkategori Kemampuan Matematis Tinggi 
Berdasarkan pada Gambar 1 bahwa siswa berkategori kemampuan matematis tinggi dengan inisial S1 sudah mampu menguasai permasalahan pada soal sehingga siswa dapat memberikan langkah-langkah pengerjaan sesuai dengan ketentuan rumus pada bunga tabungan serta sampai mendapatkan hasil akhir dan dapat menarik sebuah kesimpulan. Berdasarkan wawancara dilakukan peneliti dengan S1 diperoleh hasil informasi yaitu didapatkan bahwa S1 sudah menguasai permasalahan terdapat pada tes maka mampu menuliskan tentang diketahui dan ditanyakan sesuai berdasarkan pertanyaan, kemudian mampu menjelasakan langkah-langkah pada hasil pengerjaannya serta kesimpulan dengan benar dan merasa sudah yakin terhadap hasil pengerjannya. Pada penjelasan sebelumnya sejalan dengan penelitian (Purwaningtyas, 2019) bahwa siswa yang mempunyai kemampuan matematis tinggi pada soal tes kemampuan penalaran matematis dapat memberikan langkah-langkah pengerjaan dan memberikan kesimpulan dengan benar serta memeriksa kembali sebuah kebenaran atau dapat disebut dengan kesahihan suatu argumen. Berdasarkan pada penjelasan sebelumnya bahwa siswa berkategori kemampuan matematis tinggi dengan inisial S1 sudah terpenuhi pada indikator kemampuan penalaran matematis yakni memeriksa kesahihan suatu argumen karenakan S1 sudah melakukan langkah pengerjaan dan memahami rumus bunga tabungan pada aritmatika sosial serta memberikan kesimpulan hasil akhir.

\section{b. Kemampuan Matematis Sedang (S2)}

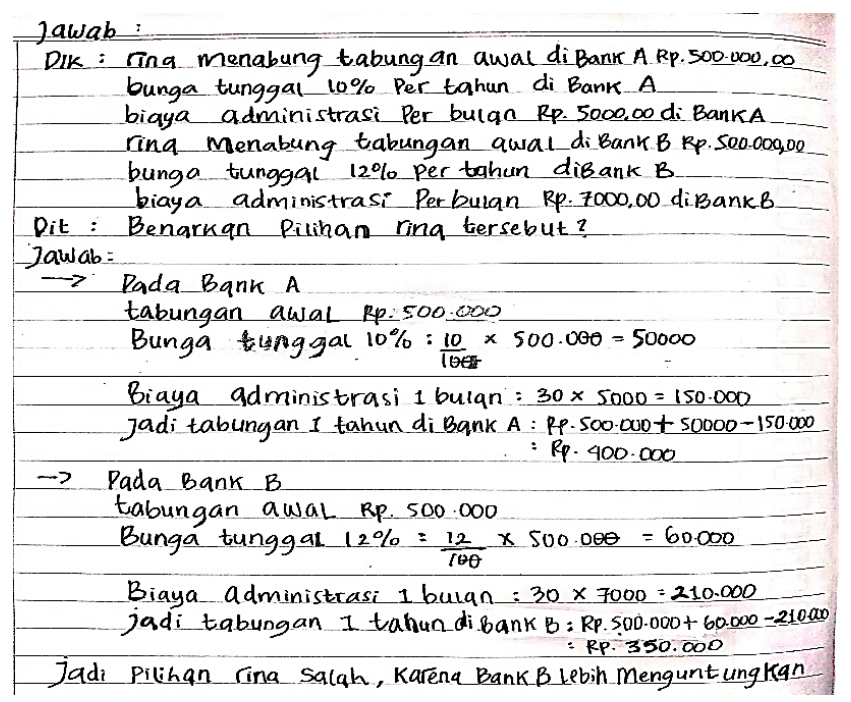

Gambar 2. Jawaban Siswa Berkategori Kemampuan Matematis Sedang

Berdasarkan pada gambar 2 bahwa siswa berkategori kemampuan matematis sedang dengan inisial S2 sudah mampu mengerjakan pertanyaan pada soal sehingga 
dapat memberikan langkah-langkah pengerjaan dan kesimpulan, namun S2 masih kurang teliti dalam mendapatkan informasi dari pertanyaan soal dimana terjadi kesalahan pada hasil biaya administrasi perbulan pada bank A dan bank B sehingga terjadi kesahalan pada hasil akhir dan kesimpulan. Berdasarkan hasil wawancara peneliti dengan S2 yaitu mendapatkan informasi bahwa S2 sudah mampu menguasai permasalahan pada soal yaitu siswa dapat menjelaskan diketahui dan ditanyakan berdasarkan pertanyaan pada soal dan siswa dapat menjelaskan langkah-langkah pengerjaannya namun hanya sedikit kurang teliti dalam mendapatkan informasi pada soal yaitu S2 memahami informasi pada biaya administrasi pada bank A dan bank B per bulan sesuai dengan perhitungan tanggal dalam sebulan, namun jawaban yang sebenarnya adalah jumlah bulan dalam setahun sehingga hasil akhir pengerjaan dan kesimpulan S2 kurang benar. Penjelasan sebelumnya sejalan dengan penelitian (Azizah et al., 2017) yaitu siswa berkemampuan sedang sudah dapat menyelesaikan permasalahan dengan menjelaskan langkah-langkah pengerjaan, tetapi masih kurang dalam menentukan jawaban dari sebuah pertanyaan pada soal kemampuan penalaran matematis. Berdasarkan dari penjelasan sebelumnya bahwa siswa berkategori kemampuan matematis sedang dengan inisial S2 sudah terpenuhi pada indikator kemampuan penalaran matematis yakni memeriksa kesahihan suatu argumen dikarenakan S2 sudah melakukan langkah pengerjaan dan memahami rumus bunga tabungan pada aritmatika sosial serta memberikan kesimpulan hasil akhir, namun masih masih terjadi kesalahan yang kecil sehingga hasil akhir menjadi kurang benar.

\section{c. Kemampuan Matematis Rendah (S3)}

Jawab:
$*$ Bunga Tunggal Pada Bank $A$
$=\frac{10}{100} \times 5.000 .000=50.000$
$*$ Bunga Tungsal Pada Bank $B$
$=\frac{12}{100} \times 5.000 .000=60.000$

Gambar 3. Jawaban Siswa Berkategori Kemampuan Matematis Rendah

Berdasarkan pada gambar 3 bahwa siswa berkategori kemampuan matematis rendah dengan inisial S3 masih kurang mampu memahami pertanyaan pada soal sehingga hanya dapat mengerjakan langkah awal tanpa melanjutkan langkah selanjutnya dan tidak memberikan kesimpulan. Berdasarkan hasil wawancara yang dilakukan peneliti dengan S3 yaitu mendapatkan informasi bahwa S3 masih kurang menguasai 
permasalahan dari pertanyaan soal dikarenakan belum dapat menjelaskan hasil pengerjaan pada langkah selanjutnya dan tidak memberikan kesimpulan. Penjelasan sebelumnya sejalan dengan penelitian (Sulistiawati et al., 2019) bahwa siswa kemampuan rendah masih belum mampu melanjutkan langkah-langkah penyelesaian serta kesimpulan, dikarena siswa masih belum memahami soal tes kemampuan penalaran matematis sepenuhnya dan tidak melakukan pemeriksaan kembali jawaban diperoleh sehingga tidak dapat menarik kesimpulan. Berdasarkan penjelasan sebelumnya bahwa siswa berkategori kemampuan matematis rendah dengan inisial S3 belum mampu terpenuhi indikator kemampuan penalaran matematis yakni memeriksa kesahihan suatu argumen dikarenakan S3 tidak melanjutkan hasil pengerjaan dikarenakan lupa dengan rumus-rumus pada bunga tabungan dan kurang mehamami informasi pada soal.

Tabel 3. Rangkuman Hasil Analisis

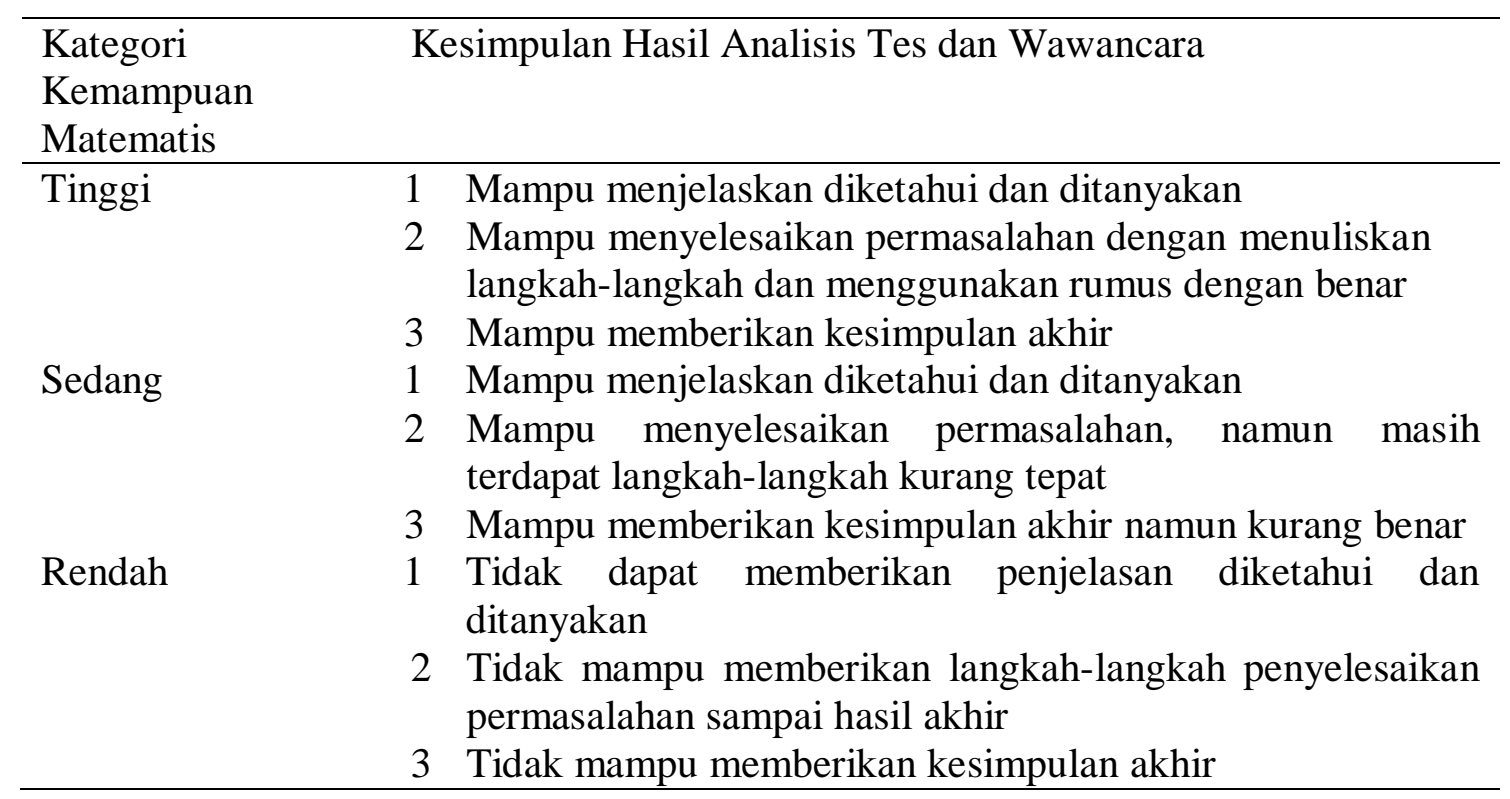

\section{Pembahasan}

Berdasarkan hasil analisis jawaban siswa yang telah dijelaskan sebelumnya bahwa dapat diberikan pembahasan pada indikator kemampuan penalaran matematis yaitu memeriksa kesahihan suatu argumen pada siswa yang mempunyai kemampuan matematis tinggi dengan inisial S1, sedang dengan inisial S2, dan rendah dengan inisial S3 sebagai berikut : 


\section{Indikator Memeriksa Kesahihan Suatu Argumen}

Berdasarkan dari hasil analisis hasil pengerjaan siswa serta wawancara pada penjelasan sebelumnya bahwa bahwa siswa berkategori kemampuan matematis tinggi dengan inisial S1 dan sedang dengan insial S2 sudah mampu memeriksa kesahihan suatu argumen pada materi aritmatika sosial dikarenakan S1 sudah mampu menuliskan serta menjelaskan dari diketahui dan ditanyakan, langkah-langkah pengerjaan dengan selesai, kemudian S2 masih terdapat kesalahan yang kecil, dan memberikan sebuah kesimpulan pada hasil akhir jawaban kurang benar, sedangkan siswa berkategori kemampuan matematis rendah dengan inisial S3 masih belum mampu memeriksa kesahihan suatu argumen pada materi aritmatika sosial dikarenakan S3 tidak dapat menuliskan serta menjelaskan dari diketahui dan ditanyakan, langkah-langkah pengerjaan tidak terselesaikan sampai hasil akhir penyelesaian, serta tidak membuat kesimpulan akhir jawaban. Penjelasan sebelumnya sejalan dengan penelitian (Ardhiyanti et al., 2019) bahwa siswa berkemampuan matematis tinggi dan sedang dapat memenuhi indikator kemampuan penalaran matematis, dikarenakan siswa dapat memberikan penjelasan diketahui dan ditanyakan, penyelesaian langkah-langkah pengerjaan, dan kesimpulan pada materi aritmatika sosial, sedangkan siswa berkemampuan matematis rendah tidak memenuhi indikator kemampuan penalaran matematis dikarenakan siswa belum memberikan penjelasan diketahui dan ditanyakan, penyelesaian langkah-langkah pengerjaan kurang lengkap, dan tidak terdapat kesimpulan pada materi aritmatika sosial. Berdasarkan penelitian dari (Hasanah et al., 2019) bahwa siswa berkemampuan matematis tinggi sudah dapat memenuhi indikator kemampuan penalaran, dikarenakan siswa telah menuliskan langkah-langkah penyelesaian dengan bernilai benar, kemudian dapat menarik kesimpulan serta memeriksa kesahihan suatu argument dengan benar. Penjelasan sebelumnya sejalan dengan penelitian dari (Putra \& Novita, 2015) bahwa siswa berkemampuan matematis tinggi mampu mengidentifikasi permasalahan, penyelesaian permasalahan dan kesimpulan bernilai benar, serta mampu memeriksa kesahihan suatu argumen. Berdasarkan penelitian dari (ERDEM \& GÜRBÜZ, 2014) bahwa siswa berkemampuan sedang sudah mampu memenuhi indikator kemampuan penalaran karena siswa mampu memahami serta melakukan penyelesaian pada permasalahan, namun tidak dapat memberikan kesimpulan terhadap kebenaran hasil jawaban. kemudian penelitian dari (Mahendra et al., 2016) mengatakan bahwa siswa berkemampuan matematis sedang 
sudah mampu memenuhi beberapa indikator kemampuan penalaran matematis karena siswa mampu memberikan penyelesaian permasalahan, namun ada sedikit kesalahan maka hasil akhir dan kesimpulan masih kurang benar. Penelitian dari (Rizqi, N.R., \& Surya, 2017) menyatakan bahwa siswa berkemampuan rendah belum mampu memenuhi indikator kemampuan penalaran matematis karena siswa tidak dapat memberikan langkah-langkah penyelesaian dan bukti dengan benar sehingga siswa memberikan kesimpulan dengan bernilai salah dan siswa tidak dapat memeriksa kesahihan suatu argumen. Penelitian dari (Mualifah \& Lukito, 2014) menyatakan bahwa siswa berkemampuan matematis rendah masih belum mampu memenuhi indikator kemampuan penalaran matematis karena siswa tidak dapat menjelaskan langkahlangkah penyelesaian sampai menemukan hasil akhir maka siswa tidak dapat memberikan sebuah kesimpulan dari hasil jawabannya.

\section{Kesimpulan dan Saran}

Berdasarkan dari hasil dan pembahasan penelitian yang dijelaskan sebelumnya yaitu siswa berkategori kemampuan matematis tinggi dan sedang sudah mampu mengaplikasikan rumus bunga tabungan dalam menyelesaikan terhadap permasalahan dengan baik, namun siswa kemampuan matematis sedang kurang teliti dalam perhitungan hasil akhir sehingga jawaban masih kurang tepat, sehingga siswa kemampuan matematis tinggi dan sedang sudah mampu menyelesaikan permasalahan pada materi aritmatika sosial dan memenuhi satu indikator kemampuan penalaran matematis yakni memeriksa kesahihan suatu argumen. Siswa berkategori kemampuan matematis rendah belum maksimal mengaplikasikan rumus bunga tabungan dan kurang memahami soal maka tidak dapat menyelesaikan permasalahan pada bunga tabungan dengan baik, sehingga siswa berkategori kemampuan matematis rendah tidak mampu menyelesaikan permasalahan pada materi aritmatika sosial dan tidak memenuhi satu indikator kemampuan penalaran matematis yakni memeriksa kesahihan suatu argumen. Berdasarkan penjelasan sebelumnya bahwa dibutuhkan sebuah saran yaitu bagi siswa supaya lebih memahami secara mendalam dan siswa dapat mengaplikasikan rumusrumus bunga tabungan dengan cara berlatihan dalam mengerjakan soal-soal berkaitan dengan materi bunga tabungan pada aritmatika sosial, kemudian bagi peneliti yang lain dapat menganalisis kemampuan matematis siswa yaitu salah satunya pada kemampuan penalaran matematis secara mendalam atau menganalisis lebih dari satu indikator kemampuan penalaran matematis. 


\section{Pustaka}

Adilla Nur, Desianty \& Nurhabibah, R. (2020). Analisis Kemampuan Matematis Siswa Dan Self Confidence Siswa SMP Pada Materi Aritmatika Sosial. Jurnal EQUATION Teori Dan Penelitian Pendidikan Matematika, 3(2), 172-181. http://dx.doi.org/10.29300/equation.v3i2.2808

Aprilianti, Y., \& Zhanty, L. S. (2019). Analisis Kemampuan Penalaran Matematik Siswa SMP Pada Materi Segiempat dan Segitiga. Journal On Education, 1(2), 524-532. https://doi.org/10.31004/joe.v1i2.167

Ardhiyanti, E., Sutriyono, S., \& Pratama, F. W. (2019). Deskripsi Kemampuan Penalaran Siswa Dalam Pemecahan Masalah Matematika Pada Materi Aritmatika Sosial. Jurnal Cendekia , 3(1), 90-103. https://doi.org/10.31004/cendekia.v3i1.82

Aziz, H. E., \& Hidayati, N. (2019). Analisis Kemampuan Penalaran Matematis Siswa SMP Pada Materi Aritmatika Sosial. Prosiding Seminar Nasional Matematika Dan Pendidikan Matematika (Sesiomadika) 2019, 3, 1-5. Retrieved From https://journal.unsika.ac.id/index.php/sesiomadika/article/view/2500

Azizah, R. F., Sunardi, \& Kurniati, D. (2017). Penalaran Matematis Dalam Menyelesaikan PISA Pada Siswa Usia 15 Tahun Di SMA Negeri 1 Jember. Kadikma, 8(1), 97-104. https://doi.org/10.19184/kdma.v8i1.5269

Burais, L., Ikhsan, M., \& Duskri, M. (2016). Peningkatan Kemampuan Penalaran Matematis Siswa melalui Model Discovery Learning. Jurnal Didaktik Matematika, 3(1), 77-86. https://doi.org/10.24815/jdm.v3i1.4639

Conner, A. M., Singletary, L. M., Smith, R. C., Wagner, P. A., \& Francisco, R. T. (2014). Identifying Kinds of Reasoning in Collective Argumentation. Mathematical Thinking and Learning, 16(3), 181-200. https://doi.org/10.1080/10986065.2014.921131

ERDEM, E., \& GÜRBÜZ, R. (2014). An Analysis of Seventh-Grade Students' Mathematical Reasoning. Çukurova Üniversitesi Eğitim Fakültesi Dergis, 44(1), 123-142. https://doi.org/10.14812/cufej.2015.007

Fitriatien, S. R. (2019). Analisis Kesalahan Dalam Menyelesaikan Soal Cerita Matematika Berdasarkan Newman. JIPMat : Jurnal Ilmiah Pendidikan Matematika, 4(1), 90-103. https://doi.org/10.26877/jipmat.v4i1.3550

Haeruman, L. D., Rahayu, W., \& Ambarwati, L. (2017). Pengaruh Model Discovery Learning Terhadap Peningkatan Kemampuan Berpikir Kritis Matematis Dan SelfConfidence Ditinjau Dari Kemampuan Awal Matematis Siswa SMA Di Bogor Timur. Jurnal Penelitian Dan Pembelajaran Matematika, 10(2), 157-168. https://doi.org/10.30870/jppm.v10i2.2040

Hasanah, S. I., Tafrilyanto, C. F., \& Aini, Y. (2019). Mathematical Reasoning: The characteristics of students' mathematical abilities in problem solving. Journal of Physics: Conference Series, 1188, 1-8. https://doi.org/10.1088/17426596/1188/1/012057

Mahendra, R., Murtafiah, W., \& Adamura, F. (2016). Profil Penalaran Siswa Kelas X SMA Dalam Menyelesaikan Masalah Persamaan Kuadrat Ditinjau Dari Kemampuan Awal Siswa. JIPM (Jurnal Ilmiah Pendidikan Matematika), 4(1), 
487-501. https://doi.org/10.25273/jipm.v4i1.837

Moneva, J. C., Yaun, R. M. N., \& Desabille, I. (2020). Fake News: Logical Reasoning Ability and Students Vulnerability. International Journal of Academic Research in Business and Social Sciences, 10(3), 761-774. https://doi.org/10.6007/ijarbss/v10-i3/7090

Mualifah, Asri Nasrotul \& Lukito, A. (2014). Profil Penalaran Siswa Dalam Pemecahan Masalah Open Ended Ditinjau Dari Kemampuan Matematika. Jurnal Mathe dunesa, 3(3),9-16. Retrieved From https://jurnalmahasiswa.unesa.ac.id/index.php/mathedunesa/article/view/12683

Mulyati, B., \& Farkhah, E. (2020). Hubungan Kecerdasan Emosional Terhadap Hasil Belajar Siswa. Progress: Jurnal Pendidikan, Akuntansi Dan Keuangan, 3(1), 4251. https://doi.org/10.47080/progress.v3i1.773

Ongcoy, P. J. B. (2016). Logical Reasoning Abilities of Junior High School Students in the Province of Cotabato, Philippines. Asia Pacific Journal of Multidisciplinary Research, 4(4), 18-21.

Permendikbud. (2016). Peraturan Menteri Pendidikan Dan Kebudayaan Nomor 21 Tahun 2016 Tentang Standar Isi Pendidikan Dasar Dan Menengah. Revista Brasileira de Ergonomia.

Purwaningtyas, K. (2019). Penalaran Siswa Smp Terhadap Soal Geometri Tipe Hots Ditinjau Dari Kemampuan Matematika. APOTEMA: Jurnal Program Studi Pendidikan Matematika, 5(2), 95-102. Retrieved From http://publikasi.stkippgribkl.ac.id/index.php/APM/article/view/260

Putra, M., \& Novita, R. (2015). Profile of secondary school students with high mathematics ability in solving shape and space problem. Journal on Mathematics Education, 6(1), 20-30. https://doi.org/10.22342/jme.6.1.1940.20-30

Rizqi, N.R., \& Surya, E. (2017). An Analysis of Students' Mathematical Reasoning Ability In VIII Grade of Sablina Tembung Junior High School. International Journal of Advance Research and Innovative Ideas in Education (IJARIIE), 3(2), 3527-3533.

Salmina, M., \& Nisa, S. K. (2018). Kemampuan Penalaran Matematis Siswa Berdasarkan Gender Pada Materi Geometri. Jurnal Numeracy, 5(1), 41-48. https://doi.org/10.46244/numeracy.v5i1.304

Sri Sumartini, T. (2015). Peningkatan Kemampuan Penalaran Matematis Siswa Melalui Pembelajaran Berbasis Masalah. Mosharafa, 4(1), 1-10. Retrieved From https://journal.institutpendidikan.ac.id/index.php/mosharafa/article/view/mv4n1_1

Sugiyono. (2018). Metode Penelitian Kuantitatif,Kualitatif dan R\&D. Bandung: Alfabeta.

Sugiyono. (2019). Metode Penelitian Pendidikan (Kuantitatif, Kualitatif, Kombinasi, $R \& D$ dan Penelitian Pendidikan). Bandung: Alfabeta.

Sulistiawati, I., Arsyad, N., \& Minggi, I. (2019). Deskripsi Penalaran Siswa dalam Pemecahan Masalah Matematika pada Pokok Bahasan Barisan dan Deret Ditinjau dari Kemampan Awal. Issues in Mathematics Education, 3(2), 111-118. https://doi.org/10.35580/imed 